\title{
R\&D Performance in the Pharmaceutical Industry: A Case Study of Egypt
}

\author{
By Iman AlAyouty
}

\begin{abstract}
In Egypt, knowledge production function estimation using firm-level panel data indicates weak $\mathrm{R} \& \mathrm{D}$ performance in pharmaceutical firms. At the micro-level, in-depth interviews with selected pharmaceutical firms reveal a low R\&D intensity, in addition to an inconsistent pattern of spending over time. Firms undertake piecemeal research projects, thus lacking a long term research vision. They put greater emphasis on R\&D of the 'development' rather than the 'basic' or 'applied' types. Other symptoms of weakness are: modest collaboration with universities in research; modest collaboration with other firms in research and/or intellectual property; and a poor capacity to innovate. At the macro level, the public R\&D system lacks good governance and sound coordination between research institutions. At both micro- and macro-levels, R\&D efforts hinder innovation, thus hindering Egypt's sustainable development and integration in today's knowledgebased economy.
\end{abstract}

Keywords: research and development, output, pharmaceutical industry, knowledge production function, in-depth interviews

\section{Introduction}

Like many developing countries, Egypt seeks to increase its research and development efforts for promoting innovation as a step towards sustainable development and deeper integration in today's knowledge-based economy. A 'steppedup' rate of innovation helps drive faster growth in output and in productivity (Porter and Stern, 2004:1). In this regard, special focus lies on R\&D-intensive industries, key among which is the pharmaceutical industry. Furthermore, pharmaceutical industry has been growing in line with Egypt's rapid population growth, and also in line with the government's effort to promote health activities that reduce endemic diseases. This will, in turn, enhance productivity even more.

According to The National Science Foundation (2010), R\&D is of three types: basic research, applied research, and development. Basic research includes activities purely aimed at acquiring new knowledge without having an immediate commercial application or use. Building on the results of basic research, applied research sets out to solve practical problem(s) and/or achieve specific commercial goals/applications. Using knowledge acquired from both basic and applied research, development yields the design and development of prototypes, as well as the production of significantly improved products and processes (U.S. Census Bureau and the National Science Foundation, 2010).

To date, research related to Egypt's pharmaceutical industry has been either descriptive, or has focused almost exclusively on the implications of the Agreement on TradeRelated Aspects of Intellectual Property Rights (TRIPS) for the industry. This paper 
therefore aims to provide an applied research work which is indeed lacking for this industry in general, and for R\&D in particular.

To assess the relation of $\mathrm{R} \& \mathrm{D}$ to output, a knowledge production function is estimated with panel data for 22 Egyptian pharmaceutical firms, over the period 2005-2013. These 22 firms are medium to large-sized firms with $50+$ employees, and are therefore the firms more likely to engage in $R \& D$, hence relevant to the study. These firms also constitute a significant 42 percent of the total number of Egyptian firms operating in the industry. The estimation results are further supported by qualitative research based on in-depth interviews with the chief executive officers of five selected pharmaceutical firms.

After the introduction, Section 2 gives the literature review; Section3 gives a profile of the industry in Egypt; Section4 delivers results of the knowledge production function estimation, and provides analysis of $\mathrm{R} \& \mathrm{D}$ performance in Egypt at the micro-level; Section 5 concludes and gives relevant policy implications.

\section{Review of Literature}

R\&D literature is voluminous, and can be broadly classified into literaturelinking $\mathrm{R} \& \mathrm{D}$ to level and growth in output and in productivity, literature examining the determinants of $R \& D$ and exploring its relation to innovation, and finally estimating returns to R\&D. Literature with relevance to Egypt is less rich and is mostly descriptive, with little empirical work, especially with application to the pharmaceutical industry.

A seminal contribution to the R\&D-output relation is Griliches (1979) where the author adopts 'knowledge production function approach' while incorporating a variable measuring "the current state of technical knowledge (determined in part by current and past R\&D expenditures)" in a standard Cobb-Douglas production function. The author follows the tradition of exploring the relation of R\&D to output through econometric estimates, but also refers to the use of historical case studies as common practice.

Similarly, Mairesse and Sassenou (1991) indicate that R\&D parameter estimates obtained from econometric methods should be "seen as abstract constructs designed to summarize and quantify approximately major phenomena, or certain important aspects of them. These methods need to be supplemented and cross fertilized by individual case studies (Mairesse and Sassenou, 1991: 26-28). Well-designed and rigorously executed case studies provide detailed descriptions and in-depth knowledge of complex phenomena.

Further to these views, surveys may contribute substantially to an explanation of interindustry differences in R\&D intensity and innovative performance (Levin et al, 1987:815). Interviews (and similar qualitative approaches) may also be carried out in an open-ended manner, thus revealing new and unanticipated information that plays a role in explaining the issue of study (Rodrik, 2008:16).

Later works of Griliches distinguish between basic and applied research. ${ }^{1}$ Griliches (1986) finds firms allocating a larger share of their R\&D expenditure to basic research to be more productive than those focusing on applied research (Griliches, 1986:147). These

${ }^{1}$ Using multiple data sets of manufacturing firms employing more than 1000 persons (ranging from the smallest data set of 386 firms to the largest of 652 ). 
findings are also aligned with Mansfield (1980) in which basic research is found to be more productivity enhancing than applied research. ${ }^{2}$

Variations on the early contributions of Griliches have greatly enhanced the R\&Doutput and productivity relation estimations. For example, Scherer (1982) developed a model regressing labour productivity on the stock of R\&D, and on the intensity of both capital and intermediates ${ }^{3}$, meanwhile introducing R\&D with a lag. Subsequently, Mairesse and Hall (1996) used of the generalized method of moments in their estimations to correct for endogeneity of output (or sales) and of capital and R\&D expenditure ${ }^{4}$.

In reference to innovation, Evangelista et al. (1997) indicate that innovation generally comes under the umbrella of technological change which stems from either formal or informal knowledge. The former is written and codified in books, manuals, patents and designs, the latter is tacit and uncodified. The authors further differentiate between technological change which consists of tangible and easily-identifiable activities such as the introduction of new machinery and equipment, and that which is intangible as evident in the generation of new ideas, inventions and innovations. Innovations were traditionally considered to be fueled by $\mathrm{R} \& \mathrm{D}$ expenditure. However, contemporary focus has shifted to other sources of innovation which are external to the firm (including: the design of capital goods (Archibugi, Cesaratto and Sirilli, 1991:300) which may be continuously modified to keep up with user needs, and the technological environment, i.e., the so-called external knowledge base (van Leeuwen and Klomp, 2002:9)).

Literature with relevance to the pharmaceutical industry in Egypt tends to be either descriptive ((see for example, Handoussa and El-Shenawy (2001) and Arif (2010)), or is centered round intellectual property protection and its implications for the industry (see for example, Shallabi (2010), Balat and Loutfi (2007), Qenawy, (2001), Subramanian and Abdel-Latif (1997)). In small reference to R\&D, Shallabi (2010) indicates that large global corporations (especially the ones undergoing restructuring) have been increasingly contracting-out their R\&D activity with possible implications for firms in developing countries to undertake such R\&D.

For Egypt, R\&D-relevant literature has focused mainly on weak national-level R\&D expenditure. In addition to expenditure, the OECD and World Bank (2010) also identifies three major hurdles facing national-level $R \& D$, some of which are also key to R\&D at the industry level. These hurdles are low expenditure, an inadequate organizational structure governing the national system of $\mathrm{R} \& \mathrm{D}$, and weak university business links in R\&D coupled with very low spending at the company level.

Indeed, national level R\&D expenditure is low. Egypt's average expenditure for 20052013 relative to GDP is 0.40 percent, lower than other MENA region countries Morocco, Tunisia and Jordan at $0.76,0.67$ and 0.43 , respectively. It is also considerably lower than high spenders like Israel (4.2 percent), Denmark (2.8 percent), and Netherlands (1.8 percent) (calculated from World Development Indicators, 2016).

\footnotetext{
2 With application to 20 U.S. industries over the period 1948-66, and 16 firms over the 1960-76 period.

${ }^{3}$ Both measured relative to labour.

${ }^{4}$ As instruments they use three-year lags of capital and R\&D.
} 
As for the organizational structure of $R \& D$, it is worth noting that the national system sponsoring R\&D in Egypt is comprised of many research centers affiliated with public universities which fall under the umbrella of the Ministry of Higher Education. In addition, large research institutions (such as the National Centre for Social and Criminological Research) which fall under the umbrella of the State Ministry for Scientific Research. Meanwhile various production and service ministries have their own research centers. All these research bodies are therefore highly fragmented and operate with different organizational frameworks. Not only do they differ in their funding rules, but they also lack a coherent framework of planning and accountability, making it extremely difficult to coordinate their activities (OECD and World Bank 2010:236-237). Analysis of the dimensions of 'innovation' (one of twelve pillars making up the Global Competitiveness Index (GCI)) provides evidence of weak university-business links and low company spending. Over the period 2006-2007 through 2013-2014, Egypt's falls among the lowest quartile of countries, with average ranks ${ }^{5}$ of 0.78 and 0.71 on 'university-industry collaboration in R\&D' and 'company spending on $\mathrm{R} \& \mathrm{D}$ ', respectively. Moreover, both factors have shown a high degree of variability over that period with an average coefficient of variation of 0.16 and 0.23 , respectively (calculated from various issues of the World Economic Forum 'Global Competitiveness Report'). Thus, not only have both factors shown a weakness as indicated in the literature, but they have further shown a degree of inconsistency over the period.

Lastly, financial incentives for R\&D purposes in Egypt remain weak. Such incentives include the government subsidizing the exchange of R\&D personnel between public and private sectors, the encouragement of joint public-private collaboration in $\mathrm{R} \& \mathrm{D}$ projects, and the competitive provision of direct funding to firms through $R \& D$ grants and soft loans (as practiced in Italy and New Zealand (OECD, 2002:11)). Other governmentsponsored financial measures include the creation of specialized financial market mechanisms such as venture capital for R\&D purposes (Mani, 2005:3). Although Egypt fares moderately well on the availability of venture capital, in general, ${ }^{6}$ it still lacks venture capital for $R \& D$ purposes

Furthermore, corporate fiscal incentives for $R \& D$ purposes including tax allowances/credit are absent in Egypt. Tax allowances allow Egypt's Income Law No. 91/2005 does not include any tax allowance of the type that permits a firm to deduct either the current ${ }^{7}$ or the full $\mathrm{R} \& \mathrm{D}$ expenses from its taxable income. Article (23) of the law merely allows a firm to deduct from its taxable income any donations made to Egyptian scientific institutions. ${ }^{8}$ (Ministry of Finance, 2005).

To sum up, Egypt's R\&D performance is evidently held back by weak universitybusiness collaboration in R\&D, the modest quality of scientific research institutions, as well as weak financial or fiscal for R\&D, all with implications for a 'low' overall capacity for innovation.

\footnotetext{
${ }^{5}$ Average rank relative to the total number of countries included in the survey for the years 2006-2007 through 2013-2014.

${ }^{6}$ On a score range of $1=$ minimum venture capital availability and $7=$ readily available venture capital, Egypt scored 3 in 2011/2012 with a rank of 41/142 (WEF 2011-2012:169).

${ }^{7}$ Namely, costs of energy and materials used for R\&D, in addition to the cost of subcontracted research.

${ }^{8}$ Provided such donations do not exceed 10 percent of the taxpayer's annual net profit.
} 


\section{Profile of the Pharmaceutical Industry in Egypt}

Over the period 2001-2013, Figure 1 shows the pharmaceutical industry assuming an average of 5 percent share in total manufacturing output, and a similar share of its value added. The share in exports averaged 3 percent, while the share in employment was 4 percent. Although not a major contributor to manufacturing employment, the industry remains an important female employer with females accounting for 32.2 percent of the total industry employees. Thus, the industry's growth has important implications for female employment.

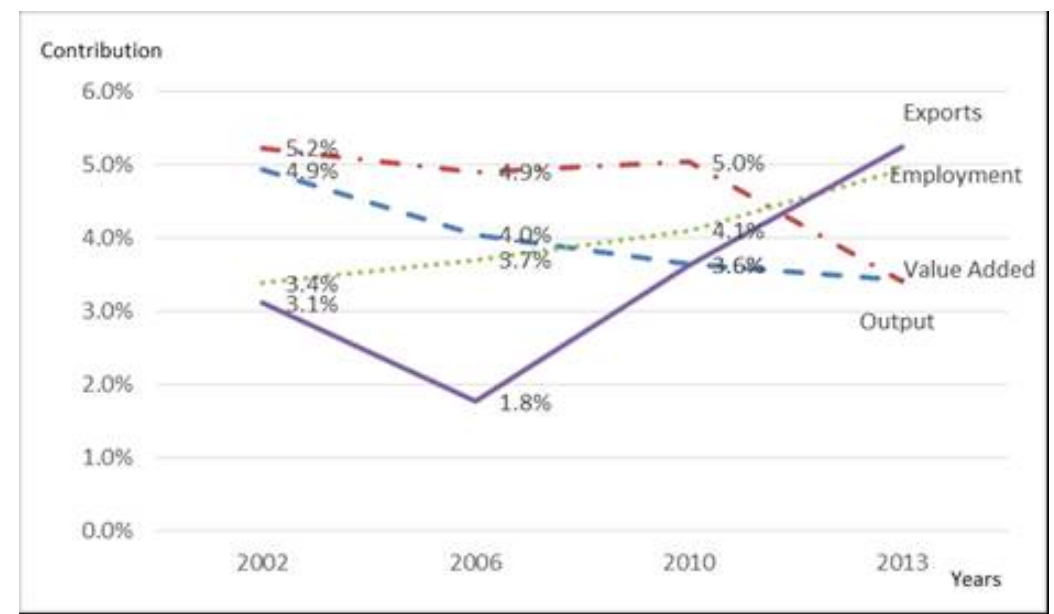

Figure 1: Pharmaceutical industry contribution to manufacturing output, value added, employment and exports, 2002-2013 2010.

Source: Author's calculations based on CAPMAS Annual Industrial Survey, different issues.

With reference to structure as shown in Table 1, the industry's output, value added, exports and employment are largely generated by firms employing more than 100 persons, the bulk of these firms employing more than 500 persons. This industry structure is yet another reason why the data used for panel model estimation was for firms of $50+$ employees.

Table 1. The contribution of large firms (100 employees persons to output, value added, employment and exports of the pharmaceutical industry (\%),2002, 2006, 2010, 2013

\begin{tabular}{lcccc}
\hline Output & $\mathbf{2 0 0 2}$ & $\mathbf{2 0 0 6}$ & $\mathbf{2 0 1 0}$ & $\mathbf{2 0 1 3}$ \\
\hline Share of firms with 100+ employees & & & & \\
$\quad$ Of which: firms with 500+ employees & 90 & 91 & 98 & 98 \\
$\quad$ Value Added & 65 & 68 & 79 & 85 \\
- Share of firms with 100+ employees & 92 & 92 & 99 & 99 \\
$\quad$ Of which: firms with 500+ employees & 67 & 72 & 78 & 86 \\
Employment & & & & \\
- Share of firms with 100+ employees & 93 & 91 & 99 & 99 \\
Of which: firms with 500+ employees & 76 & 74 & 87 & 90 \\
\hline
\end{tabular}




\begin{tabular}{lrrrr}
\hline Exports & & & & \\
- Share of firms with 100+ employees & 86 & 90 & 90 & 98 \\
Of which: firms with 500+ employees & 60 & 37 & 82 & 92 \\
\hline
\end{tabular}

Source: Author's calculations based on CAPMAS Annual Industrial Survey, different issues.

Note:

- Data for public sector firms is for FY 2001/02, 2005/06, 2009/10, and 2012/2013, while data for private sector are for the calendar years 2002, 2006, 2010 and 2013.

- For the years 2002 and 2006, CAPMAS Annual Industrial Survey's adopted the ISIC Revision 3.1, accordingly distribution of the above variables by firm size was given for the chemical industry at large (as Rev.3.1 includes pharmaceuticals together with "code 24: manufacture of chemicals and chemical products"). For 2010 onwards, CAPMAS adopted Revision 4 under which the pharmaceuticals are entered separately under "code 21: manufacture of basic pharmaceutical products and pharmaceutical preparations."

\section{The Empirical Model and Analysis Pertaining to R\&D Performance in Egypt}

This section presents the estimation of the panel data model, and the results of the in-depth interviews conducted with five pharmaceutical firms. These interviews aimed to show whether the low $\mathrm{R} \& \mathrm{D}$ expenditure and weak organizational structure which have been found to hinder macro-level R\&D and innovation are also hindering it at the firm-level.

\subsection{The empirical model}

Following variations of models estimated by Griliches (1979, 1986), Mansfield (1980), Mairesse and Sassanou (1991), a Cobb-Douglas functional form of production is estimated ${ }^{9}$ using a panel of 22 pharmaceutical firms in Egypt employing more than 50 persons ${ }^{\circ}$ ver the period 2005-2013. Of the 22 firms, 7 are public sector ${ }^{10}, 14$ are private sector firms.

$\mathrm{Y}_{i t}=\mathrm{ALL}_{i t}^{\beta_{1}} \mathrm{~K}_{i t}^{\beta_{\mathrm{k}}} \mathrm{R}_{i t}{ }^{\beta_{\mathrm{r}}} e^{u_{i t}}$

$i=1, \ldots, 22 ; t=1, . ., 9$

Where, $\mathrm{A}=$ state of technology (i.e., total factor productivity);

$\mathrm{Y}_{i t}=$ value of real output of firm $i$ at point $t$ in time;

$\mathrm{L}_{i t}=$ total number of employees in firm $i$ at point $t$ in time;

$\mathrm{K}_{i t}=$ value of real capital stock of firm $i$ at point $t$ in time;

$\mathrm{R}_{i}=$ value of real $\mathrm{R} \& \mathrm{D}$ expenditure of firm $i$ at point $t$ in time.

Taking the logarithm of both sides, renders the following empirical specification:

$\log \left(\mathrm{Y}_{i t}\right)=\log (\mathrm{A})+\boldsymbol{\beta}_{l} \log \left(\mathrm{L}_{i t}\right)+\boldsymbol{\beta}_{k} \log \left(\mathrm{K}_{i t}\right)+\boldsymbol{\beta}_{r} \log \left(\mathrm{R}_{i t}\right)+u_{i t}$

Estimate of $\log (\mathrm{A})$ is TFP, $\beta_{\mathrm{l}}, \beta_{\mathrm{k}}$ and $\beta_{r}$ are measures of the elasticity of output with respect to labour, capital and $\mathrm{R} \& \mathrm{D}$, respectively, and $u_{i t}$ is the error term assumed to

\footnotetext{
9 To name but a few other recent applied works: Rogers (2010), Wang and Tsai (2003); Loof and Heshmati (2002); Wakelin (2000), Ug Kwon and Inui (2003).

${ }^{10}$ For perspective, 52 firms operated in the industry in the year 2013. 8 of these were public sector and 44 were private sector firms.
} 
behave normally. The Hausman specification test concludes that the appropriate specification is that of a random effects specification. Furthermore, the Hausman-Wu test for potential endogeneity between R\&D and output was conducted, and concluded that there is indeed no endogeneity.

Output is measured as the value of output at sales price (i.e., the market value of output). Using the perpetual inventory, the value of capital (i.e., stock of fixed assets at year end) is constructed from accumulated past investments and the depreciation of the existing capital stock. The depreciation rate for the capital stock was calibrated from Hevia and Loayza (2011) at 0.06 (as per the rate deduced in the study for the depreciation of capital stock in Egypt's industry). Labour is measured as total employed by the firm, while R\&D is flow of expenditure over one year. Output, capital and $\mathrm{R} \& \mathrm{D}$ expenditure are all deflated using the GDP deflator to reflect real values.

$\mathrm{R} \& \mathrm{D}$ is also used in its lagged form to test for whether R\&D yields positive effects after a given gestation period. Gestation may also be associated with the nature of innovation undertaken. If innovation is of the 'product' type, gestation may result from the time it takes for the innovation to be recognized and completely commercialized. If it is of the 'process' type, gestation may result from the gradual introduction of the process itself (Griliches, 1979:101, Griliches, 1986:145 and CBO, 2005:12).

\subsubsection{Data sources}

Firm level pharmaceutical data were specially queried ${ }^{11}$ from the electronic database of the annual industrial survey issued by Egypt's Central Agency for Public Mobilization and Statistics (CAPMAS). Data for GDP deflator were drawn from the World Bank "World Development Indicators".

\subsubsection{Estimation Results}

Model estimation results are given in Table 2:

Table 2. Knowledge production function estimation results

\begin{tabular}{|lcc|}
\hline & $(\mathbf{1})$ & $(\mathbf{2})$ \\
Intercept term $(\boldsymbol{\alpha})$ & $7.046888^{* * *}$ & $7.8378^{* * *}$ \\
Capital & $(1.028146)$ & $(0.625)$ \\
Labour & $0.02142^{* *}$ & $0.0194^{*}$ \\
& $(0.010439)$ & $(0.0117)$ \\
R\&D Expenditure & $0.581789^{* * *}$ & $0.4962^{* * *}$ \\
& $(0.135938)$ & $(0.0668)$ \\
R\&D Expenditure $\mathbf{( - 1 )} \mathbf{( 1 )}^{(\mathbf{1}}$ & $0.100101^{* * *}$ & \\
S.E. of regression & $(0.029820)$ & $0.0681^{* * *}$ \\
F-value & & $(0.0115)$ \\
\hline
\end{tabular}

Source: Author's estimation.

11 Firm level data in Egypt is not made available to researchers except with prior authorization for use from CAPMAS. To ensure that firms' data confidentiality is not breached, CAPMAS performs its own coding of firms prior to making data available for use. 
Note : ***, ** and $*$ indicate the estimated parameter is statistically significant at the $1 \%$, $5 \%$ and $10 \%$ levels respectively; heteroscedastic-consistent standard errors of estimates in parentheses.

(1) The appropriate lag structure is 1-yr lag. Akaike information criterion was lowest compared to 2- and 3-yr lags in R\&D (2.226 versus 2.291 and 2.357, respectively). However, the lags were tested separately in a pooled OLS regression.

Results (1) and (2) reflect a positive elasticity of output with respect to all factors, albeit with R\&D showing a low value coefficient. Literature forwards some possible explanations for low-value $\mathrm{R} \& \mathrm{D}$ coefficient in estimated knowledge production functions pertaining either to the macro- or micro-level(s), or to both (shown between parentheses): R\&D expenditure into productivity gains owing to inadequate organizational structures and/or low R\&D personnel intensity and an insufficient level of skills among employees (macro and micro) (Ortega-Argiles, Piva and Vivarelli, 2011:9); unsuitable structures of corporate governance (macro); weak university-business links (macro and micro); lack of fiscal incentives for the promotion of R\&D investment (macro); poor utilization of the system of intellectual property rights (macro); (Rogers, 2010:335). Indeed all have been identified above for Egypt.

\subsection{Micro-level analysis pertaining to $R \& D$ performance in Egypt}

Five in-depth interviews (IDIs) were conducted with firms of different ownership structures (see Appendix for selection criteria). Questions addressed in the IDIs were drawn from the annual "Business Research and Development and Innovation Survey" administered by the U.S. National Science Foundation. The focus of the IDI questions was on: expenditure; the nature of research carried out; introduction of 'new' and 'improved' products and processes; patents and intellectual property; R\&D personnel. Findings were as follows:

\subsubsection{Firm-level expenditure on $R \& D$}

Firm-level R\&D intensity in Egypt is was found to be $1-2 \%$. This is low compared to international practices. For perspective, the National Science Foundation estimates average annual R\&D intensity for U.S. pharmaceutical firms to be around 8-10 percent (Source: CBO, 2006:9).

Two explanations may be given for the low R\&D intensity in Egypt's firms. First, firms' $\mathrm{R} \& \mathrm{D}$ expenditure is primarily oriented to $\mathrm{R} \& \mathrm{D}$-related material (e.g., for laboratory use), instruments and equipment, not covering the salaries of R\&D personnel. Internationally, firms' R\&D expenditure covers current and capital expenditure, the former covering both personnel and materials used in $\mathrm{R} \& \mathrm{D}$, the latter covering $\mathrm{R} \& \mathrm{D}$-related instruments, equipment, land, buildings, and computer software (Source: UNESCO, 2008:6)). Second, all interviewed firms (except MNS) attested that they budget their annual R\&D expenditure not as a percentage of forecasted sales revenue but rather as an estimate of their operational needs for the upcoming year. They therefore possessed no specific research agenda, rendering their $\mathrm{R} \& \mathrm{D}$ more of the development type, as opposed to basic or applied type. 


\subsubsection{The effect of the firms' organizational structure on their capacity to translate $R \& D$ expenditure into output or productivity gains}

Intra-firm, R\&D carried out was mainly of the development type, with no evidence of basic or applied research. Such absence of basic and applied research may also relate to the fact that the interviewed firms (like the majority of Egypt's pharmaceutical firms) produce either off-patent generics, drugs under license, or drugs invented prior to 1995 (hence not subject to TRIPS). As such, they may lack the incentive to conduct the type of research that yields new products or processes, lending them more oriented to the development-type research.

As for intra-firm propensity to innovate (measured by ability to introduce (or pioneer) new or improved products and processes relying on own formal research (Lam, 2004:3-5; WEF, 2011-2012:13)), firms showed no evidence of new products or processes, but merely of some process improvements. This is probably not separate from their meager $\mathrm{R} \& \mathrm{D}$ expenditure that might not sustain the cost of introducing new products, for example.

Inter-firm, there was no evidence of either vertical or horizontal collaboration, of forming strategic alliances or peer-firm consortia, or of taking part in technical cooperation or technology exchange arrangements. With universities, at best, firms solicited the consultancy of public-university academics for carrying out specific research tasks, with no clear pattern of firm-university collaboration in research.

In sum, the interviewed firms all fall short of the organizational structure required for translating R\&D into output or productivity gains. This is mainly due to: the nature of $\mathrm{R} \& \mathrm{D}$ undertaken; their propensity to introduce only improved (as opposed to new) products and processes; their limited scope for inter-firm and firm-university collaboration in research; their limited scope for inter-firm collaboration in intellectual property.

\subsubsection{The effect of R\&D employee intensity on the firms' capacity to translate $R \& D$ expenditure into output or productivity}

$\mathrm{R} \& \mathrm{D}$ personnel intensity (R\&D personnel relative to total employees) in the interviewed firms was in the 1-2 percent range. Such intensity falls short of international intensities. For example, pharmaceutical R\&D employee intensity in some of the EU member states in the year 2007 was as follows: Slovakia 3.0 percent; Poland 3.8, Romania 4.1 percent, and Czech Republic 5.3 percent. Figures for member states with higher pharmaceutical R\&D employee intensities are 27.4 percent in the Netherlands and 26.3 percent in Denmark (Eurostat, 2008).

Overall, R\&D employee intensity appears low, yet again another factor limiting firms' capacity to translate $\mathrm{R} \& \mathrm{D}$ expenditure into output or productivity gains.

\section{Concluding Remarks}

Egypt's macro-level R\&D issues vary. Modest public expenditure is coupled the absence of a well-defined medium-to-long national R\&D strategy. Also, the public R\&D system lacks good governance, and there is near absence of coordination between public institutions and businesses. Financial and fiscal incentives to R\&D are either weak or 
lacking. All these issues are almost completely mirrored at the micro-level.

Egypt needs to raise public R\&D expenditure from the present low level. In addition to furthering knowledge creation at the level of public research entities, higher expenditure should also create space for R\&D grants and soft loans to be allocated to large and small private sector firms, enabling government support of firm-level R\&D.

Egypt is also often criticized for still being in need of a well-defined medium-to-long term national strategy for $\mathrm{R} \& \mathrm{D}$ - one that includes both public and private sectors and spans the whole range of economic activities. Pharmaceuticals do not appear to rank high on Egypt's research priorities. Recognition of the role of R\&D in driving this industry's growth should help direct Egypt's government to rank this industry high on its $\mathrm{R} \& \mathrm{D}$ priority list.

At present, the R\&D system is described as "bureaucratic and bloated," lacking sound coordination of the R\&D efforts of public institutions with many instances of duplicated and redundant efforts. It remains of great importance that Egypt's R\&D strategy spell out a division of responsibility among public research institutions, together with having a good governance structure with adequate monitoring and evaluation mechanisms in place.

As for the coordination between public institutions and businesses, the national strategy needs to strengthen university-business links to ensure that public research is demanddriven. Moreover, once public funds are available for R\&D efforts of large and small firms, they must be competitively allocated. These two issues were, in fact, targeted by three R\&D initiatives begun by Egypt's government in 2007. They included the establishment of: the Higher Council for Science and Technology; the Science and Technology Competitive Fund; an R\&D programme in cooperation between the State Ministry of Scientific Research and the European Union. The three initiatives simultaneously aimed for a demand-driven public research and the promotion of competitive-based R\&D funding ${ }^{12}$ (OECD and World Bank, 2010:239). With nine years elapsing, the initiatives still do not appear to have borne fruit.

From an industrial policy standpoint, Egypt's government must attempt to initiate some viable fiscal incentives such as tax allowances to promote $\mathrm{R} \& \mathrm{D}$. The present income tax law includes no allowance of this nature. The government may also consider introducing financial tools such as venture capital for R\&D. Various venture capital practices are presently in place but none are earmarked for R\&D. We note that firm-level evidence indicates that many of Egypt's firms produce off-patent generic drugs. In this regard, however, the interviewed firms indicated that they face legislative constraints that hinder them from tapping into potential products or innovating on existing generics. Such constraints include the ministry of health permitting the registration of a product only if it has an exact generic counterpart in reference countries (in dosage form and all product characteristics, reaching as far as enclosing the exact drug leaflet).

We further note that Egypt may promote a steady supply of its scientific and technical labour, thus mobilizing resources for $\mathrm{R} \& \mathrm{D}$, through encouraging the study of science, mathematics and engineering to increase graduates. Egypt's university graduates are

12 In addition to the enhancement of participation of Egyptian research institutions in the European research area. 
heavily concentrated in 'humanities and social sciences' as opposed to 'science and engineering' (in 2010/2011, 80\% of higher education graduates were in the humanities and social sciences versus $20 \%$ in sciences and engineering. Respective shares were $65 \%$ and $35 \%$ in 2013/2014) ${ }^{13}$ (Calculated from CAPMAS 2011a and CAPMAS 2014). Thus, reform of the education system should aim at balancing skills on the supply side with demand priorities on the side of labour market.

The IDIs have made it evident that the need for a well-defined R\&D strategy is a problem that is not typical of the macro-level alone, but also of the micro-level. As such, firms tend to undertake piecemeal projects addressing practical or operational problems with no vision of long-term research. This has a bearing on their R\&D expenditure being relatively modest and inconsistent year-after-year, as well as on their research being mostly of the development as opposed to basic or applied types. It further reflects on firms' lack of interest to commission projects to universities or to undertake them jointly. Firms also appear to have no scope for inter-firm collaboration in research or in intellectual property. Their overall propensity to innovate remains limited with virtually no introduction of new products or processes, but only some improved ones.

Overall, pharmaceutical firms appear to lack the organizational structure required for translating R\&D into output or productivity gains. At the national level, Egypt should spend more on R\&D, set well-defined targets that can be achieved over the medium to long term via public-private coordination, give incentives to firms to innovate, improve the educational system and develop the organizational structure to achieve productivity gains from $R \& D$ at the firm level. As previously said, $R \& D$ is key to sustainable development specifically through its effect on productivity. This is key to Egypt's integration in today's knowledge based economy. Herein lie lessons for other developing countries.

\section{References}

Archibugi, D., Cesaratto S. \& Sirilli G. (1991). Sources of Innovative Activities and Industrial Organization in Italy. Research Policy, 20, 299-313.

Arif, F. M. E. (2010). “Al-meeza attanafusiaya lissena'at adwe'iya al-misriya fil aswaq al-afriqiya (al-foras wattahadiyat)." Misr al-mu'asra (Contemporary Egypt), 498. Al-jam'iya al-misriya lil iqtisad al-siyasi wa tashri': Cairo.

Balat, M. A.F \& Loutfi, M. H. (2007). The TRIPs Agreement and Developing Countries: A Legal Analysis of the Impact of the New Intellectual Property Rights Law on the Pharmaceutical Industry in Egypt,' First published 2004 in the Web Journal of Current Legal Issues. Retrieved from http://webjcli.ncl.ac.uk/2004/issue2/balat2.html"'

Braha, D. \& Bar-Yam,Y. (2004). Information Flow Structure in Large-Scale Product Development Organizational Network. In Vervest P. et al. (eds.), Smart Business Networks (Springer: U.S.A) Retrieved from http://www.necsi.edu/projects/braha/springerchapter08danbraha.pdf

CAPMAS (Central Agency for Public Mobilization and Statistics of Egypt), 2011a, Statistical Yearbook (CAPMAS: Cairo).

CAPMAS, 2011b, Egypt in Figures. CAPMAS: Cairo.

CAPMAS. (2014). Statistical Yearbook (CAPMAS: Cairo).

13 Please note that humanities and social sciences are included in the yearbook as "theoretical faculties" versus sciences and engineering included as "practical faculties". 
CBO (Congressional Budget Office of the Congress of the United States). (2005). R\&D and Productivity Growth: Background paper. Retrieved from http://www.cbo.gov/ftpdocs/64xx/docs6482/0617-R-D.pdf.

CBO (2006). Research and Development in the Pharmaceutical Industry. Retrieved from http://www.cbo.gov/sites/default/files/cbofiles/ftpdocs/76xx/doc7615/10-02-drugr-d.pdf

Chandan, S. (2011). R\&D and Productivity in the Indian Pharmaceutical Firms,' Munich Personal RePEc Archive Paper no. 31681. Retrieved from http://mpra.ub.unimuenchen.de/31681/1/MPRA_paper_31681.pdf

Eurostat. (2008). Statistics in Focus 91/2008: R\&D Expenditure and Personnel. Retrieved from http://epp.eurostat.ec.europa.eu/cache/ITY_OFFPUB/KS-SF-08-091/EN/KS-SF-08-091EN.PDF

Evangelista, R., Perani, G., Rapiti, F. \& Archibugi, D. (1997). Nature and Impact of Innovation in Manufacturing: Some Evidence from the Italian Innovation Survey. Research Policy, 26, 521-536. Retrieved from http://www.danielearchibugi.org/downloads/papers/Evangelista_et_al_Research_Policy.pdf

Freel, M. S. (2000). Strategy and Structure in Innovative Manufacturing SMEs: the Case of an English Region. Small Businsess Economics, 15, 27-45.

Griliches, Z. (1979). Issues in Assessing the Contribution of Research and Development to Productivity Growth. Bell Journal of Economics, 10, 92-116.

Griliches, Z. (1986). Productivity, R\&D and Basic Research at the Firm Level in the 1970s. American Economic Review, 76, 141-54.

Griliches, Z. \& Lichtenberg, F. (1984). Interindustry Technology Flows and Productivity Growth: A Reexamination. The Review of Economics Statistics, 66, 324-29.

Griliches, Z. \& Mairesse, J. (1985). Productivity Growth in Japanese and U.S. Manufacturing Firms. National Bureau of Economic Research Working Paper no. 1778. Retrieved from ideas.repec.org/p/nbr/nberwo/1778.html.

Hagedoorn, J. (1993). Understanding the Rationale of Strategic Technology Partnering: Inter-organizational Modes of Cooperation and Sectoral Differences. Strategic Management Journal, 14, 371-385.

Hall, B. H. (1996). The Private and Social Returns to Research and Development. In Smith, B. and C. Barfield (eds.), Technology, R\&D and the Economy (Brookings Institute, U.S.A.) Retrieved from http://elsa.berkeley.edu/ bhhall/papers/BHH96\%20\%R\&Dreturns.pdf

Hall, B. H. \& Lerner, J. (2009). The Financing of R\&D and Innovation. In Hall, B.H. and N. Rosenberg (eds.), Handbook of the Economics of Innovation (Elsevier: North Holland). Retrieved from http://emlab.berkeley.edu/ bhhall/papers/HallLerner09_rndfin_chapter_draft.edf

Handoussa, H. and El-Shinnawy, A. (2004). Egyptian Case Studies. In S. Estrin and K. E. Meyer (eds.), Investment Strategies in Emerging Markets (Massachusetts: Edward Elgar). Retrieved from http://www.mafhoum.com/press7/226E2.pdf

Hevia, C. and N. Loayza, 2011, 'Savings and Growth in Egypt,' World Bank Policy Research Working Papers no. 5529, World Bank, Washington, DC. Retrieved from http://elibrary.worldbank.org/doi/pdf/10.1596/1813-9450-5529

IMS (Intercontinental Marketing Services). (2002) . World Review 1999. In S. Estrin and K.E. Meyer (eds.), Investment Strategies in Emerging Markets, (Edward Elgar, UK).

IMS (2011). IMS Pharmaceutical World Review Executive 2011.Retrieved from http://www.imap.com/imap/media/resources/IMAP_PharmaReport_8_272B8752E0FB3.pdf

Lam, A. (2004). Organizational Innovation. BRESE (Brunel Research in Enterprise, Innovation, Sustainability and Ethics) Working Paper no.1. Retrieved from http://mpra.ub.unimuenchen.de/11539/1/BRESE_org_innovation_Lam_WP1.pdf

Levine, R., Klevorick, A. K. , Nelson, R. R., \& Winter, S. G. (1987). Appropriating the Returns from Industrial Research and Development. Brookings Papers on Economic Activity, 3, 783-820.

Lööf, H., \& Heshmati, A. (2002). On the Relationship between Innovation and Performance: A Sensitivity Analysis. Retrieved from elsa.berkeley.edu/ bhhall/EINT/Loof_Heshmati.pdf

Mani, S. (2005). How Governments Can Boost Business R\&D. Science and Development Network Policy Brief. Retrieved from http://www.scidev.net/policy-briefs/how-governments-can-boostbusiness-r-d.html 
Mansfield, E. (1980). Basic Research and Productivity Increase in Manufacturing. The American Economic Review, 70, 863-73.

Mairesse, J. \& Sassenou, M. (1991). R\&D and Productivity: A Survey of Econometric Studies at the Firm Level. National Bureau of Economic Research Working Paper no. 3666. Retrieved from http://www.nber.org/papers/w3666.pdf

Mairesse, J. \& Hall, B. H. (1996). Estimating the Productivity of Research and Development: An Exploration of GMM Methods Using Data of French and United States Manufacturing Firms. National Bureau of Economic Research Working Paper no. 550. See Retrieved from http://www.nber.org/papers/w5501.pdf

Ministry of Finance Egypt. (2005). The Income Tax Law No. 91 of 2005. Retrieved from http://www.mof.gov.eg/MOFGallerySource/english/IncomeTaxLaw.pdf

OECD (Organization for Economic Cooperation and Development) (2002). Tax Incentives for Research and Development: Trends and Issues. Retrieved from http://www.metutech.metu.edu.tr/download/tax\%20incentives\%20for\%20R\&D. pdf"

OECD \& the World Bank (2010). Reviews of National Policies for Education: Higher Education in Egypt. Retrieved

from http://siteresources.worldbank.org/INTEGYPT/Resources/REPORTHigherEducationinEgypt2010FINAL-ENGLISH.pdf

Ortega-Argiles, Piva, R., M., \& Vivarelli, M. (2011). The Transatlantic Productivity Gap: Is R\&D the Main Culprit? Paper presented at the $3^{\text {rd }}$ European Conference on Corporate R\&D and Innovation, Spain, October 6. Retrieved from http://iri.jrc.ec.europa.eu/concord2011/papers/Ortega_Raquel.pdf (accessed November 21, 2011).

Porter, M. \& Stern, S. (2004). Ranking National Innovative Capacity: Findings from the National Innovative Capacity Index. In Xavier Sala-i-Martin (ed.) The Global Competitiveness Report 2003-2004, (Oxford University Press: New York. Retrieved from http://www.isc .edu/Innov_9211.pdf

Qenawy, E. M. (2001). 'Al-Ahamiya al-iqtisadiya litiffaqiyat al-milkiya al-fikriya: derassa maydaniya bittatbiq 'la sina'at al-dawa' fi misr,' Misr al-mu'asra (Contemporary Egypt) 463, (Al-jam'iya al-misriya lil iqtisad al-siyasi wa tashri', Cairo).

Rodrik, D. (2008). The New Development Economics: We shall Experiment, but How Shall We Learn?', Faculty Research Working Paper Series no. 08-055. Retrieved from http://www.hks.harvard.edu/fs/drodrik/Research\%20papers/The $\% 20 \mathrm{New} \% 20$ Development $\% 2$ 0 Economics.pdf

Rogers, M. (2010). R\&D and Productivity: Using UK Firm-level Data to Inform Policy. Empirica, 37, 32959 .

Scherer, F. M. (1982). Inter-industry Technology Flows and Productivity Growth. The Review of Economics and Statistics, 64, 627-34.

Shallabi, M. (2010). "Itiffaqiyat al-gawaneb al-mutassila bil-tigara fi hoqoq al-milkiya al-fikriya wa athariha 'la sina'at al-dawa." Misr al-mu'asra (Contemporary Egypt), 498, (Al-jam'iya al-misriya lil iqtisad al-siyasi wa tashri': Cairo).

Subramanian, A. \& Abdel-Latif, M. (1997). The Egypt-EU Partnership Agreement and the Egyptian Pharmaceutical Sector. The Egyptian Center for Economic Studies Working Paper no. 11, ECES: Cairo.

Ug Kwon, H.\& Innui, T. (2003). R\&D and Productivity Growth in Japanese Manufacturing Firms. Economic and Social Research Institute Discussion Paper no. 44. Retrieved from http://www.esri.go.jp/jp/archive/e_dis/e_dis050/e_dis044a.pdf

UNESCO (United Nations Educational, Scientific and Cultural Organization). (2008). Measuring Research and Experimental Development (Part 3). Workshop on 'Science, Technology and Innovation Indicators', Bostwana, September 22-25. Retrieved from http://www.unesco.org/new/fileadmin/MULTIMEDIA/HQ/SC/pdf/sc_workshop_botswana_ measuring3_en.pdf

U.S. Census Bureau and the National Science Foundation. (2010). 2010 Business Research and Development and Innovation Survey. Retrieved from http://www.nsf.gov/statistics/srvyindustry/about/brdis/

Van Leeuwen, G. \& Klomp, L. (2002). On the Contribution of Innovation to Multi-factor Productivity Growth.

Retrieved

from http://emlab.berkeley.edu/users/bhhall/EINT/Van_Leeuwen_Klomp.pdf 
Wakelin, K. (2000). Productivity Growth and R\&D Expenditure in UK Manufacturing Firms. Center for Research on Globalization and Labour Markets Research Paper no. 2000/20. Retrieved from http://dspace.cigilibrary.org/jspui/bitstream/123456789/19210/1/Productivity\%20Growth\%20a nd $\% 20 \mathrm{R} \% 20$ and $\% 20 \mathrm{D} \% 20$ Expenditure $\% 20$ in $\% 20 \mathrm{UK} \% 20$ Manufacturing $\% 20$ Firms.pdf?1

Wang, J. \& Tsai, K. (2003). Productivity Growth and R\&D Expenditure in Taiwan's Manufacturing Firms. National Bureau of Economic Research Working Paper Series no. 9724. Retrieved from http://www.nber.org/papers/w9724.pdf

WEF (World Economic Forum). (2006-2007). The Global Competitiveness Report. WEF: Geneva.

WEF. (2007-2008). The Global Competitiveness Report. WEF: Geneva.

WEF. (2008-2009). The Global Competitiveness Report. WEF: Geneva.

WEF. (2009-2010). The Global Competitiveness Report. WEF: Geneva.

WEF. (2010-2011). The Global Competitiveness Report. WEF: Geneva.

WEF. (2011-2012). The Global Competitiveness Report. WEF: Geneva.

WEF. (2011). The Executive Opinion Survey 2011: The Global Competitiveness Report of the World Economic Forum. WEF: Geneva.

WEF. (2012-2013). The Global Competitiveness Report,' WEF: Geneva.

WEF. (2013-2014). The Global Competitiveness Report', WEF: Geneva.

World databank, World Development Indicators and Global Development Finance. Retrieved from http://databank.worldbank.org/ddp/home.do?Step=1\&id=4 (accessed October 20, 2011).

\section{Appendix: Criteria for Selecting Pharmaceutical Firms for In-Depth Interviews}

In a study of this nature, pharmaceutical firms would have typically been selected for indepth interviews based on the level of their R\&D expenditure. However, due to the absence of published annual firm-specific R\&D expenditure data, ${ }^{14}$ firms were selected based on ownership structure, market share, market capitalization at end of November 2011 (for those whose stocks are traded on Egypt's Stock Exchange), range of export markets, size of employment and contribution to the total employment of the pharmaceutical industry. Ownership structure ranges from: privately-owned Egyptian firm operating under the 'Company Law 159/1981' (PRE); public sector firms operating under 'Public Sector Law 203/1991'(PBE); firms of joint private and public Egyptian equity operating under 'Public Sector Law 203/1991' (PREPBE); firms of Egyptian and foreign private capital operating under 'Investment Law 8/ 1997'(PREPRF); wholly-owned subsidiaries of multinational corporations operating in Egypt under 'Investment Law 8/1997'(MNS).

Data on the above indicators used for selection were compiled from Kompass Egypt Financial Yearbook 2010/2011, Egypt Stock Exchange website (at www.egx.com.eg), the Annual Industrial Survey issued by CAPMAS, and Intercontinental Marketing Services 2002). Initially the following number of firms were located: 6 PREs; 1 PBE; 5 PREPBE; 6 PREPRFs; 9 MNSs. Naturally, this is not an exhaustive coverage of all firms operating in the industry, but rather those firms for which data was accessible and which fell under all the identified ownership structures.

Firms were arranged in each category based on the highest market capitalization, market share, contribution to pharmaceutical industry employment, and the widest range of export markets. The R\&D-related issues probed in IDIs can be broadly grouped into: introduction of new (or improved) products and/or processes; nature of research carried out and expenditure on it; strategy for $\mathrm{R} \& \mathrm{D}$; human resources engaged in $\mathrm{R} \& \mathrm{D}$; patents and intellectual property.

\footnotetext{
${ }^{14}$ Whereby such expenditure is not revealed in income statements.
} 